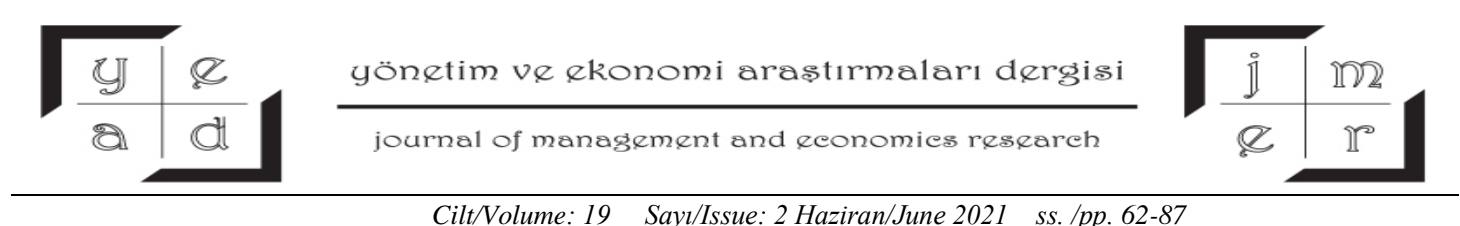

Cilt/Volume: 19 Sayl/Issue: 2 Haziran/June 2021 ss./pp. 62-87

S. Şahin Doi: http://dx.doi.org/10.11611/yead.877321

\title{
THE EFFECT OF CONSUMER CONFIDENCE ON AGGREGATE HOUSEHOLD CONSUMPTION AND LEVERAGE
}

\section{Dr. Serçin ŞAHIN * iD}

\begin{abstract}
The concept of consumer confidence and its effects on macroeconomic variables have been subject to extensive research since it was devised in the 1940s. Empirical studies suggest that it is one of the leading causes of macroeconomic fluctuations through its effects on household consumption. Consumer durables spending and household borrowing in particular are found to be sensitive to consumer confidence. In this study, a stock-flow-consistent system dynamics model is developed to explain how consumer confidence affects aggregate household behavior and the macroeconomic dynamics of the economy. The simulation results confirm that consumer confidence strongly affects the economy's dynamic behavior and households' psychological parameters determine the stability properties of the economy.
\end{abstract}

Key Words: Consumer Confidence, Consumption, Borrowing, Stock-Flow-Consistent Framework, System Dynamics, Simulation.

JEL Codes: E21, E27, E71, B59.

\section{TÜKETICI GÜVENININ TOPLAM HANEHALKI TÜKETIMİ VE KALDIRACI ÜZERİNE ETKISI}

\section{ÖZET}

1940'larda kavramsal olarak ortaya çıkışından bu yana, tüketici güveni ölçütleri ve bunların makroekonomik değişkenler üzerindeki etkilerine ilişsin birçok araştırma yapılmıştır. Bazı ampirik çalışmalar, tüketici güveninin hanehalkı tüketimi üzerindeki etkileri aracıllğıyla makroekonomik dalgalanmaların en önemli nedenlerinden biri olduğunu ortaya koymuştur. Özellikle, dayanıkl tüketim malı harcamaları ve hanehalkı borçlanması tüketici güvenine oldukça duyarlıdır. Bu çalışmada, tüketici güveninin toplam hanehalkı davranışını ve tüm ekonomiyi nasıl etkilediğini açıklamak üzere stok-akımtutarlı bir sistem dinamiği modeli gelişstirilmiştir. Simülasyon sonuçları tüketici güveninin ekonominin dinamik davranışını güçlü bir biçimde etkilediğini teyit etmiştir. Bunun yanında, ekonomideki psikolojik parametrelerin ekonominin istikrarlılı̆̆ını belirlediği ortaya konulmuştur.

\footnotetext{
${ }^{*}$ Y 1 diz Technical University, Faculty of Economic and Administrative Sciences, Department of Economics. İstanbul/ Turkey. E-mail: sesahin@yildiz.edu.tr
}

\section{Makale Gecmiși/Article History}


Anahtar Kelimeler: Tüketici Güveni, Tüketim, Borçlanma, Stok-Akım-Tutarlı Modelleme Çerçevesi, Sistem Dinamiği, Simülasyon.

JEL Kodları: E21, E27, E71, B59.

\section{INTRODUCTION}

Indices measuring consumer confidence constitute one of the most important sets of data carefully followed by the public and policy-makers all around the world. George Katona created this concept in the 1940s. Based on his concept, the University of Michigan's Institute for Social Research started to conduct surveys to measure attitudes and expectations of US households, and as a result, constituted the Index of Consumer Sentiments (ICS), which has been published since 1952 (Katona, 1968). It has proved to be an important leading indicator providing information about the situation of the economy, and similar indices, intended to measure consumer sentiments of households, have been created and regularly published in numerous countries.

Katona $(1951,1975)$ defines consumer sentiment as the subjective psychological state of consumers which is formed by the digestion of various economic and non-economic stimuli and has profound effects on their economic decisions and actions (Vuchelen, 2004). Research on the neurophysiological structures working in the human decision-making process has revealed supportive evidence for the effects of psychological factors on economic decisions. While the prefrontal cortex is the center for deliberate reasoning regarding our actions and their consequences, more primitive parts of our brains are also involved in our decisions through subconscious motivational mechanisms (Loewenstein and O'donoghe, 2004). Adam Smith pointed out this distinction in his work The Theory of Moral Sentiments (2002) by arguing that human behavior is shaped by both an 'impartial spectator' that makes rational decisions and 'passions' comprising emotional states and instincts (Loewenstein and O'donoghe, 2004).

When the rational expectations assumption was widely adopted in the 1970s, the psychological effects became excluded from economics (Geiger, 2016). Mainstream economic theories tend to take consumer confidence as a superficial variable that solely reflects the fully rational expectations about the future of the economy and income (Geiger, 2016). For example, the proponents of the life-cycle and permanent income theories of consumption assert that consumer sentiment is nothing more than a better indicator of expected future income than the extrapolation of past observation of income (Throop, 1992). Even if consumer sentiment was accepted as a separate variable and each consumer were to react to stimuli differently with the effect of these sentiments, the aggregate behavior would not be affected by these differences because they would be canceled out due to the law of large numbers (Katona, 1947). In brief, mainstream economic theories solely elaborate on conscious mechanisms governed by the prefrontal cortex (Loewenstein and O'donoghe, 2004) and leave psychological factors outside the realm of 'rationality' (Dow and Dow, 2011). 
In contrast, Keynesian tradition -particularly, the post-Keynesian tradition- regards consumer confidence (or 'animal spirits') as a part of the rationality developed to deal with the problem of uncertainty (Dow and Dow, 2011). Keynes argues that human decisions and actions cannot be based solely on rational reasoning and must be supported by animal spirits because of fundamental uncertainty (Dow and Dow, 2011). In his work A Treatise on Probability (1921), Keynes distinguishes probability and the weight of expectations. Probability is a function of the difference between favorable and unfavorable evidence. On the other hand, weight is a function of the completeness of the evidence. Subsequently, in his General Theory (1936), he uses the term confidence instead of weight and argues that long-term expectations are a function of the forecast and the degree of confidence in them. Low confidence indicates a lack of enough evidence for justifying the action (Marchionatti, 1999). Therefore, due to the uncertainty about the future of the economy, decisions, especially long-term, are based on sentiment (Franke, 2012). Moreover, we cannot simply assume that the effects of these sentiments will cancel out in the aggregate behavior. If the sentiments of economic agents are correlated due to factors such as the influence of mass media, these effects would add up and drive the aggregate behavior (Katona, 1947).

Many studies found empirical evidence regarding the relation between consumer sentiments and economic aggregates such as income, consumption, borrowing, and saving. For example, Blanchard (1993) and Carroll, Fuhrer and Wilcox (1994) found that the main reason behind the 1990-91 recession in the US was a consumption shock resulting from a drop in consumer confidence. Cote and Johnson (1998) found that consumer confidence contains information beyond expectations of income and this information improves the fit of the consumption equation. Katona (1957) and Bryant and Macri (2005) showed that changes in consumer sentiment occur prior to changes in discretionary consumption expenditures. Garner (1981), Hymans (1970), Juster and Wachtel (1972), Katona (1949, 1971), Pickering (1993) and Throop (1992) found that consumer sentiment affects spending on consumer durables significantly. Katona (1968) found that the index for consumer sentiment is significant for predicting consumer installment debt even after controlling for income. Juster and Wachtel (1972) and Mishkin $(1976,1978)$ showed that consumer confidence affects both consumption and saving and explained their findings with precautionary saving behavior. According to this view, consumer sentiment is a measure of uncertainty or the perceived probability of financial distress. When consumer confidence decreases, the probability of financial distress increases, and consumers shy away from illiquid assets; namely, they reduce consumer durables expenditures and increase savings to accumulate liquid assets as a buffer against unfavorable future contingencies.

As the discussion above suggests, consumer confidence profoundly affects household consumption, saving, borrowing behaviors, and, therefore, aggregate income. It would also be an important determinant of household leverage, which can be defined as the ratio of total household debt to household net worth. In this study, we develop and simulate a stock-flow-consistent system dynamics 
model to understand the structure of the economy and determine the effects of a change in consumer confidence on aggregate household income, consumption, and leverage. The simulation results of our model show that the equilibrium level of household income, consumption, and leverage is determined by consumer confidence, and the psychological characteristics of households determine the dynamics and stability properties of the economy.

This study is organized as follows: After this introduction, in Section 2, we give some brief information on the stock-flow-consistent framework and system dynamic methodologies. In Section 3, we explain the dynamic hypothesis and our model. Section 4 presents the result of this model. Section 5 summarizes the conclusions.

\section{METHODOLOGY}

In this paper, we built a System Dynamics (SD) model based on the Stock-Flow Consistent (SFC) Framework. The SFC framework relies on a careful distinction between stock and flow variables. Each agent in the economy is represented with a balance sheet, and the flows of goods and funds between the agents are carefully recorded to understand the dynamics of the economy. The SFC framework is particularly useful for modeling the financial relations between economic agents and their effects on the economy. ${ }^{1}$ Furthermore, SD is a methodology used to understand the dynamic behavior of complex adaptive systems. As SD relies on the assumption that the systems' dynamic behaviors emerge from their internal structures, these structures are modeled using tools such as stock and flow variables, causal relationships, delays, and feedback loops. Then, these SD models are simulated to analyze the dynamic behavioral patterns of systems and carry out policy experiments to improve the performance of the systems. $^{2}$

The SFC framework provides the rules to track the goods and fund flows between economic agents in the economy. SD methodology provides the tools to model and simulate the possibly nonlinear structure of the economy. Therefore, SD can fruitfully be used together with the SFC framework to understand the structure and behavior of the economy.

\section{MODEL}

The dynamic hypothesis representing the causal relationships between variables is given in Figure 1. There are three sectors in the model: Households (h), firms (f), and banks (b). To focus on the dynamics of consumer behavior, we simplified the behavior of firms and banks. Their equities are normalized to zero. Furthermore, to focus on just the dynamics arising from real variables, we excluded

\footnotetext{
${ }^{1}$ To get comprehensive information on the Stock-Flow-Consistent framework, please see Godley and Lavoie (2006).

${ }^{2}$ To get comprehensive information on the System Dynamic methodology please see Sterman (2000).

Yönetim ve Ekonomi Araștırmaları Dergisi / Journal of Management and Economics Research
} 
the price, wage, and interest rate adjustment mechanisms. Notably, the price level is normalized to 1; hence, nominal quantities also correspond to real quantities.

Figure 1. Dynamic Hypothesis

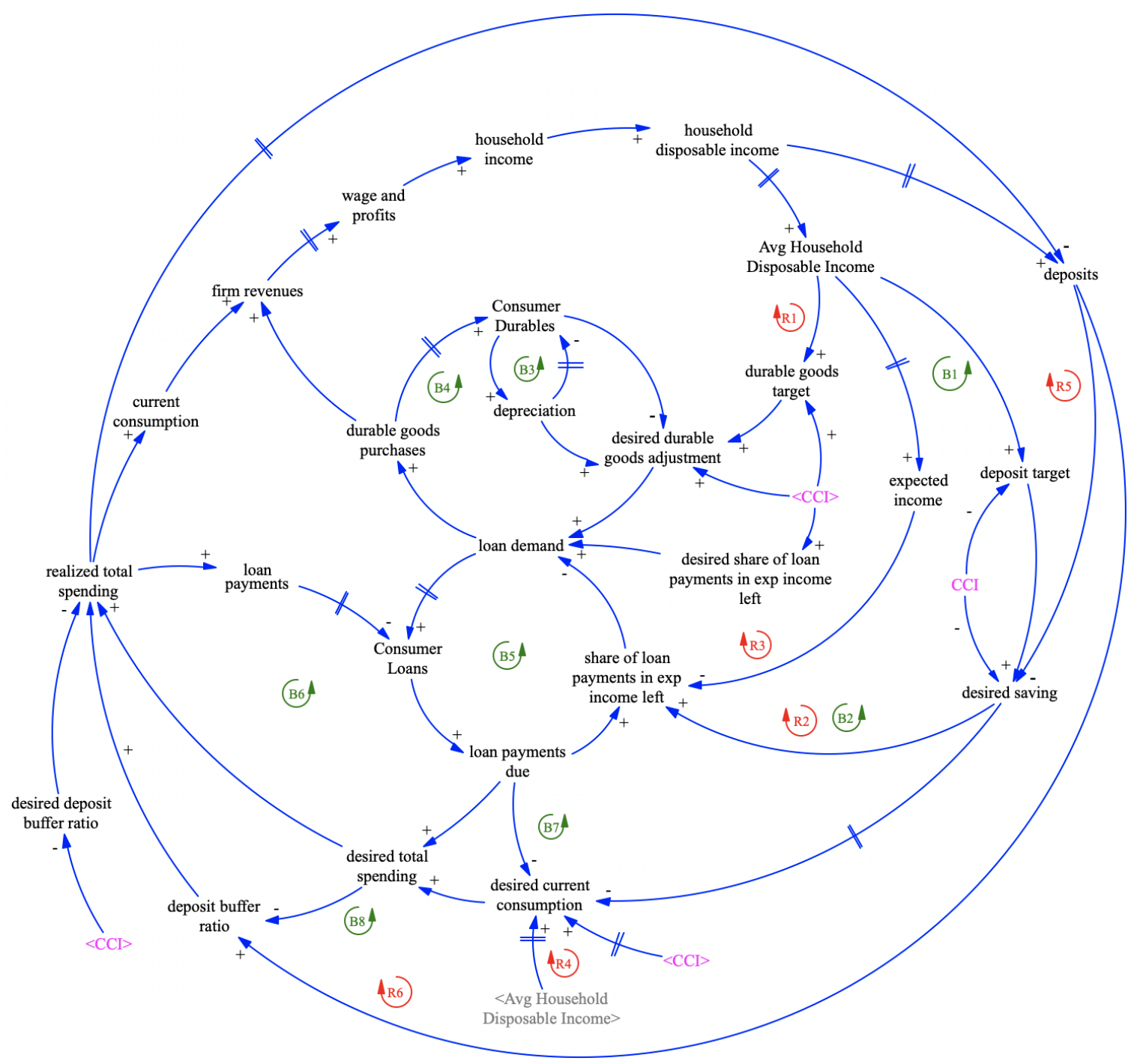

Variables in the model can be either stock or flow, which are denoted with a boldface font $(\mathbf{X})$ and a regular font (X), respectively. Regarding stocks, we denote sectors that hold it as an asset on its balance sheet with a subscript and sectors that hold it as a liability with a superscript. As for flows, we denote sectors for which the flow causes an increase in assets or a decrease in liabilities (use of funds) with a subscript; and sectors for which the flow causes an increase in liabilities or a decrease in assets (source of funds) with a superscript. Variables and parameters with a "tilde" ( $\widetilde{\mathrm{X}})$ indicate their "desired" or "planned" levels, those with a "hat" $(\widehat{\mathrm{X}})$ indicate their target levels, and, those with a "bar" $(\overline{\mathrm{X}})$ indicate the normal or average levels. Finally, the estimated or expected value of a variable is denoted with an expectation function, $\mathrm{E}[\mathrm{X}]$. 
The balance sheet and transaction matrices of the economy are given in Tables 1 and 2, respectively.

Table 1. The Balance Sheet of the Economy

\begin{tabular}{|l|c|c|c|c|}
\hline & Households & Firms & Banks & \multicolumn{1}{|c|}{} \\
\hline Consumer Durables & $+\boldsymbol{D} \boldsymbol{R}_{\boldsymbol{h}}$ & & & $+\boldsymbol{D} \boldsymbol{R}_{\boldsymbol{h}}$ \\
\hline Deposits & $+\boldsymbol{D} \boldsymbol{P}_{\boldsymbol{h}}^{\boldsymbol{b}}$ & $+\boldsymbol{D} \boldsymbol{P}_{\boldsymbol{f}}^{\boldsymbol{b}}$ & $-\boldsymbol{D} \boldsymbol{P}^{\boldsymbol{b}}$ & 0 \\
\hline Loans & $-\boldsymbol{L}^{\boldsymbol{h}}$ & & $+\boldsymbol{L}_{\boldsymbol{b}}$ & 0 \\
\hline Net Worth & $-\boldsymbol{N} \boldsymbol{W}^{\boldsymbol{h}}$ & $-\boldsymbol{N} \boldsymbol{W}^{\boldsymbol{f}}$ & $-\boldsymbol{N} \boldsymbol{W}^{\boldsymbol{b}}$ & $-\boldsymbol{D} \boldsymbol{R}_{\boldsymbol{h}}$ \\
\hline$\Sigma$ & 0 & 0 & 0 & 0 \\
\hline
\end{tabular}

Table 2. The Transaction Matrix of the Economy

\begin{tabular}{|c|c|c|c|c|c|}
\hline & \multicolumn{2}{|c|}{ Households } & \multirow{2}{*}{ Firms } & \multirow{2}{*}{ Banks } & \multirow{2}{*}{$\Sigma$} \\
\hline & Current & Capital & & & \\
\hline Current Consumption & $-C_{0}-C C^{h}$ & & $+C_{0}+C C_{f}$ & & 0 \\
\hline Cons. Durable Purchases & & $-C D^{h}$ & $+C D_{f}$ & & 0 \\
\hline Amortization & $-\delta D \boldsymbol{R}_{h}$ & $+\delta \boldsymbol{D} \boldsymbol{R}_{h}$ & & & 0 \\
\hline Wages and Profits & $+W P_{h}$ & & $-W P^{f}$ & $-W P^{b}$ & 0 \\
\hline \multicolumn{6}{|l|}{ INTEREST ON: } \\
\hline Bank Deposits & $+r^{d p} \boldsymbol{D} \boldsymbol{P}_{\boldsymbol{h}}^{\boldsymbol{b}}$ & & $+r^{d p} \boldsymbol{D} \boldsymbol{P}_{\boldsymbol{f}}^{\boldsymbol{b}}$ & $-r^{d p} \boldsymbol{D} \boldsymbol{P}^{\boldsymbol{b}}$ & 0 \\
\hline Loans & $-I P^{h}$ & & & $+I P_{b}$ & 0 \\
\hline \multicolumn{6}{|c|}{ CHANGE IN STOCKS OF: } \\
\hline Bank Deposits & & $-\frac{d}{d t} \boldsymbol{D} \boldsymbol{P}_{\boldsymbol{h}}^{\boldsymbol{b}}$ & $-\frac{d}{d t} \boldsymbol{D} \boldsymbol{P}_{\boldsymbol{f}}^{b}$ & $+\frac{d}{d t} D P^{b}$ & 0 \\
\hline Loans & & $+\frac{d}{d t} L^{h}$ & & $-\frac{d}{d t} \boldsymbol{L}_{b}^{h}$ & 0 \\
\hline$\Sigma$ & 0 & 0 & 0 & 0 & 0 \\
\hline
\end{tabular}

\subsection{Households}

Households hold consumer durables $\left(\boldsymbol{D} \boldsymbol{R}_{\boldsymbol{h}}\right)$ and bank deposits $\left(\boldsymbol{D} \boldsymbol{P}_{\boldsymbol{h}}^{\boldsymbol{b}}\right)$ as assets and loans $\left(\boldsymbol{L}_{\boldsymbol{b}}^{\boldsymbol{h}}\right)$ and net worth $\left(\boldsymbol{N} \boldsymbol{W}^{\boldsymbol{h}}\right)$ as liabilities (Eq.1).

$$
D R_{h}+D P_{h}^{b}=L_{b}^{h}+N W^{h}
$$

\subsubsection{Household Income}

Households own firms and banks; therefore, firms' and banks' revenues accrue to households in the form of wages and profits. Since this is an aggregate model, we do not distinguish between the two. Household income $\left(Y_{h}\right)$ is equal to the sum of wages and profits from firms and banks $\left(W P^{f}, W P^{b}\right)$, and deposit (DP $\boldsymbol{P}_{\boldsymbol{h}}^{\boldsymbol{b}}$ ) interest income (Eq.2).

$$
Y_{h}=W P^{f}+W P^{b}+r^{d p} \boldsymbol{D} \boldsymbol{P}_{\boldsymbol{h}}^{\boldsymbol{b}}
$$

Since there is no government in the model, we assume that household disposable income is equal to their income (Eq.3)

$$
Y D_{h}=Y_{h}
$$


Households' behavioral patterns rely on habits, which gradually change (Katona, 1949, 1968, 1980). We call the whole of these habits 'standard of living' and assume that it is determined by households' perceived average disposable income $\left(\overline{Y D}_{h}\right)$, which adjusts to the actual disposable income with a partial adjustment process (Eq.4). We use standard of living and perceived average disposable income terms interchangeably.

$$
\frac{d}{d t} \overline{Y D}_{h}=\frac{1}{T_{1}}\left(Y D_{h}-\overline{Y D}_{h}\right)
$$

Here, $T_{1}$ is the time horizon of households, in which perceived disposable income is adjusted.

Households observe the growth rate of the perceived average disposable income (Eq.5). The average growth rate of perceived average disposable income $\left(\bar{g}_{h}\right)$ is also updated with a partial adjustment process (Eq.6). The expected disposable income is the extrapolation of current perceived average disposable income with this rate (Eq.7).

$$
\begin{gathered}
g_{h}=\frac{1}{T_{1}}\left(\frac{Y D_{h}}{\overline{Y D}_{h}}-1\right) \\
\frac{d}{d t} \bar{g}_{h}=\frac{1}{T_{1}}\left(g_{h}-\bar{g}_{h}\right) \\
E\left[\overline{Y D}_{h}\right]=\left(1+\bar{g}_{h}\right) \overline{Y D}_{h}
\end{gathered}
$$

\subsubsection{Portfolio Choice, Desired Saving and Desired Discretionary Consumption}

We assume that household wealth consists of consumer durables and bank deposits. Consumer durables are illiquid assets that are held primarily for the consumption services they provide (Mishkin, 1976). In contrast, bank deposits are liquid assets, the primary function of which is to act as a buffer stock against the risk of inability to service debt commitments and to maintain the current level of standard of living (Carroll, 1992; Katona, 1974; Tobin, 1958).

Households have a target wealth level which is a positive function of their standard of living (Katona, 1974; Pickering, 1993). Therefore, households' total wealth target is assumed to be a multiple $(\varpi)$ of their perceived average disposable income (Eq.8).

$$
\widehat{\boldsymbol{W}}_{\boldsymbol{h}}=\varpi \bar{Y}_{h}
$$

As consumer durables are financed with consumer loans, households would be willing to acquire more consumer durables when they are more confident about their ability to repay these loans. However, when consumers are less confident about their future personal economic conditions, they will be willing to accumulate more liquid assets with precautionary motives (Bertola, Guiso and Pistaferri, 2005; Carroll, 1992, 2004; Carroll and Samwick, 1995), and reduce the share of illiquid assets in their portfolio (Kindleberger and Aliber, 2005; Mishkin, 1978; Throop, 1992). Therefore, in our model, the desired 
share of consumer durables in target wealth increases, and the desired share of bank deposits decreases with consumer confidence.

As these assets are imperfect substitutes, the desired share of consumer durables in household target wealth $(\rho)$ is assumed to be determined with a logistic function (Eqs.9 and 10). There is a desire for the rest of the target wealth to be held in bank deposits (Eq.11).

$$
\begin{gathered}
\rho=\frac{1}{1+e^{-\gamma_{1}(C C I-1)}} \\
\widehat{\boldsymbol{D R}}_{\boldsymbol{h}}=\rho \widehat{\boldsymbol{W}}_{\boldsymbol{h}} \\
\widehat{\boldsymbol{D P}}_{\boldsymbol{h}}^{\boldsymbol{b}}=(1-\rho) \widehat{\boldsymbol{W}}_{\boldsymbol{h}}
\end{gathered}
$$

Here $\gamma_{1}>0$ is the sensitivity parameter.

Consumer confidence is measured with the Consumer Confidence Index (CCI), which takes values between zero and two $(0<C C I<2)$, with a normal value of 1 . In this model, we assume that $\mathrm{CCI}$ is an exogenous variable.

The desired saving is determined with a stock-adjustment process (Eq.12). Households have a desire to save $\left(\tilde{S}_{h}\right)$ out of their disposable income to close the gap between their target and actual levels of bank deposits in deposit adjustment time $\left(T_{2}\right)$.

$$
\tilde{S}_{h}=\frac{\widehat{\boldsymbol{P P}}_{\boldsymbol{h}}^{\boldsymbol{b}}-\boldsymbol{D} \boldsymbol{P}_{\boldsymbol{h}}^{\boldsymbol{b}}}{T_{2}}
$$

The deposit adjustment time is also a function of CCI (Carroll, 1992; Deaton, 1991; Dees and Brinca, 2013; Sandmo, 1970). Namely, when CCI is high, consumers would be less eager to reach the bank deposits target (Eq.13). In this equation, $\bar{T}_{2}$ is the normal level of deposit adjustment time when $\mathrm{CCI}$ is equal to $1 . \gamma_{2}>0$ is the sensitivity parameter.

$$
T_{2}=\bar{T}_{2}(C C I)^{\gamma_{2}}
$$

The remaining part of average discretionary income after desired saving, if any, is equal to the amount that households are willing to spare for discretionary consumption. However, the level of desired discretionary consumption $\left(\widetilde{C C}_{h}\right)$ relies on habits; therefore, it slowly adjusts to the new levels (Eq.14).

$$
\frac{d}{d t} \widetilde{C C}_{h}=\frac{\max \left[\left(\overline{Y D}_{h}-C_{0}-\widetilde{L P}_{h}-\tilde{S}_{h}\right), 0\right]-\widetilde{C C}_{h}}{T_{3}}
$$

$T_{3}$ is the desired discretionary consumption adjustment time, which is a function of CCI (Eq.15). Notably, as CCI increases, households would adjust faster to new levels of desired discretionary consumption. In this equation, $\bar{T}_{3}$ is the normal level of desired discretionary consumption adjustment time when $\mathrm{CCI}$ is equal to $1 . \gamma_{3}>0$ is the sensitivity parameter. 


$$
T_{3}=\bar{T}_{3}(C C I)^{-\gamma_{3}}
$$

\subsubsection{Desired Consumer Durables Demand and Loan Demand}

Consumer durables demand is commonly modeled in the literature with a stock-adjustment process (Grieves, 1983;Hymans, 1970; Juster and Wachtel, 1972; Mishkin, 1976). In order to reach the consumer durables target in consumer durables adjustment time $\left(T_{4}\right)$, households have a desire to purchase some part of the difference between the actual and target levels, in addition to the depreciated stock (Eq.16).

$$
\widetilde{C D}_{h}=\frac{\widehat{D R}_{\boldsymbol{h}}-\boldsymbol{D} \boldsymbol{R}_{\boldsymbol{h}}}{T_{4}}+\delta \boldsymbol{D} \boldsymbol{R}_{\boldsymbol{h}}
$$

The consumer durables adjustment time $\left(T_{4}\right)$ is also affected by CCI. Specifically, when CCI is high, consumers would be hasty to reach the consumer durables target (Eq.17). $\bar{T}_{4}$ is the normal consumer durables adjustment time when $\mathrm{CCI}$ is equal to $1 . \gamma_{4}>0$ is the sensitivity parameter.

$$
T_{4}=\bar{T}_{4}(C C I)^{-\gamma_{4}}
$$

For the sake of simplicity, we assume that consumers finance all of their consumer durables purchases with loans. Therefore, the primary determinant of loan demand is the desired consumer durables purchases. Another factor effective on loan demand is the share of loan payments due $(\theta)$ in expected income left after desired saving and necessities (Eq.18).

$$
\Theta=\frac{\widetilde{L P}_{h}}{E\left[Y D_{h}\right]-C_{0}-\tilde{S}_{h}}
$$

Keynes argues that the economic system runs on borrowing and lending relations based on margins of safety, which are required by economic agents to provide safety against the possibility of unfavorable economic contingencies (Minsky, 1977). We assume that households would like to keep their loan payments at a certain share $(\widetilde{\Theta})$ of their expected average disposable income left after desired savings and necessities, in order to leave a margin of safety. This desired share is a function of CCI; namely, the more confident households are about the future, the lower the margin of safety and vice versa (Eq.19).

$$
\widetilde{\Theta}=\bar{\Theta}(C C I)^{\gamma_{5}}
$$

Here $\bar{\Theta}$ is the normal share of loan payments when CCI is equal to 1 , and $\gamma_{5}>0$ is the sensitivity parameter. The actual share of loan payments relative to its desired level affects the new loan demand via an inverse-S-shaped function (Eq.20). As the actual share of loan payments increases relative to its desired level, the loan demand decreases (Eq.21). 


$$
\begin{gathered}
\Phi=f\left(\frac{\Theta}{\widetilde{\widetilde{\Theta}}}\right) \\
L D_{h}=\Phi \widetilde{C D}^{h}
\end{gathered}
$$

The realized consumer durables purchases are determined by the realized amount of loans (Eq.22).

$$
C D^{h}=L R_{h}
$$

As consumer durables depreciate at a constant rate $(\delta)$, the change in consumer durables stock is equal to the difference between consumer durables purchases and depreciation (Eq.23).

$$
\frac{d}{d t} \boldsymbol{D} \boldsymbol{R}_{\boldsymbol{h}}=C D^{h}-\delta \boldsymbol{D} \boldsymbol{R}_{\boldsymbol{h}}
$$

\subsubsection{Realized Consumption and Realized Loan Payments}

The sum of necessities $\left(C_{0}\right)$, desired discretionary consumption $\left(\widetilde{C C}^{h}\right)$, and loan payments due $\left(\widetilde{L P}^{h}\right)$ constitute the desired total spending $\left(T S^{h}\right)$ of households (Eq.24).

$$
\widetilde{T S}^{h}=C_{0}+\widetilde{C C}^{h}+\widetilde{L P}^{h}
$$

As the primary purpose of bank deposits is to act as a buffer stock against the risk of financial distress, households are willing to hold a multiple of their desired total spending as a buffer $(\Upsilon)$ to be able to maintain the current level of spending for some time in case of an income loss. The desired level of the buffer-stock ratio is also a function of CCI; specifically, it decreases when households are more confident and vice versa (Eq.25).

$$
\Upsilon=\bar{\Upsilon}(C C I)^{-\gamma_{6}}
$$

Here $\bar{\Upsilon}$ is the normal level of the desired buffer-stock ratio when CCI is equal to 1 , and $\gamma_{6}>0$ is the sensitivity parameter. The actual level of buffer-stock ratio $(\Upsilon)$ is found as the ratio of the current level of bank deposits to desired total spending (Eq.26).

$$
\Upsilon=\frac{\boldsymbol{D} \boldsymbol{P}_{\boldsymbol{h}}^{\boldsymbol{b}}}{\widetilde{T S}^{h}}
$$

The realized total spending of households is determined with an S-shaped function, the argument of which is the ratio of the actual level of buffer-stock ratio relative to its desired level (Eq.27). The more the actual buffer-stock ratio decreases below its desired level, the more households cut their spending. However, since they have to pay for necessities under all circumstances, the spending cut applies to just the discretionary consumption and loan payments part of total spending (Eq.28).

$$
\Lambda=f\left(\frac{\Upsilon}{\bar{\Upsilon}}\right)
$$




$$
T S^{h}=\Lambda\left(\widetilde{C C}^{h}+\widetilde{L P}^{h}\right)+C_{0}
$$

Wadud et al.(2020) argues that a loan delinquency is a strategic choice between not being excluded from credit markets and keeping the readily available resources for future spending. Therefore, in our model, households do not necessarily pay the whole amount of loan payments due; they use the realization ratio of total desired spending after necessities $(\Lambda)$ to allocate the amount to be spent between loan payments and discretionary consumption with an S-shaped function (Eqs.29 and 30). The share of loan payments decreases as the realization ratio decreases.

$$
\begin{gathered}
\Gamma=f(\Lambda) \\
L P^{h}=\Gamma \Lambda \widetilde{L P}^{h}
\end{gathered}
$$

The amount of realized total spending left after realized loan payments and necessities is spent on discretionary consumption (Eq.31).

$$
C C^{h}=T S^{h}-L P^{h}-C_{0}
$$

Households' total consumption is equal to the sum of necessities, discretionary consumption, and consumer durables purchases (Eq.32).

$$
C^{h}=C_{0}+C C^{h}+C D^{h}
$$

\subsubsection{Realized Savings}

Realized savings $\left(S_{h}\right)$ are equal to the change in the level of bank deposits, hence, the difference between cash inflows and cash outflows (Eq.33).

$$
\frac{d}{d t} \boldsymbol{D} \boldsymbol{P}_{\boldsymbol{h}}^{\boldsymbol{b}}=S_{h}=Y D_{h}-T S^{h}
$$

\subsubsection{Household Leverage}

Household leverage is defined as the ratio of debt to net worth (Eq.34).

$$
L V_{h}=\frac{\boldsymbol{L}_{\boldsymbol{b}}^{\boldsymbol{h}}}{\boldsymbol{N} \boldsymbol{W}^{\boldsymbol{h}}}
$$

\subsection{Firms}

In order to focus on the dynamics of consumption, we simplified the behavior of the firms. All firms in the economy are private companies owned by households. Their equities are normalized to zero, and they do not retain any part of their profits. Firms do not have any physical capital and use labor as the only factor in production. Hence, all of their earnings are distributed to households in the form of either wages or profits. We assume that firms always have enough capacity to meet consumer demand and do not hold inventory. They hold bank deposits as assets for receiving and making payments and net worth is their only liability (Eq.35). 


$$
D P_{f}^{b}=N W^{f}
$$

The total demand for the goods firms produce is equal to total household consumption. Since firms meet all the demand for their goods by assumption, their sales are equal to total demand. Firms also receive interest income for their deposits in the bank; therefore, their total revenues $\left(R_{f}\right)$ is equal to the sum of their sales and interest income (Eq.36).

$$
R_{f}=C^{h}+r^{d p} \boldsymbol{D} \boldsymbol{P}_{\boldsymbol{f}}^{\boldsymbol{b}}
$$

Out of total revenues, firms pay households for their labor services to produce goods and distribute the remaining part as profits. Therefore, all of firms' revenues are transferred in the form of either wages or profits $\left(W P^{f}\right)$ to households with a constant delay (Eq.37).

$$
W P^{f}=R_{f-1}
$$

The net change in the firm's bank deposits is equal to the difference between total revenues and wage and profit payments in the current period (Eq.38).

$$
\frac{d}{d t} \boldsymbol{D} \boldsymbol{P}_{\boldsymbol{f}}^{b}=R_{f}-W P^{f}
$$

\subsection{The Banking Sector}

Banks hold loans $\left(\boldsymbol{L}_{\boldsymbol{b}}\right)$ on the asset side, deposits $\left(\boldsymbol{D} \boldsymbol{P}^{\boldsymbol{b}}\right)$ and net worth $\left(\boldsymbol{N} \boldsymbol{W}^{\boldsymbol{b}}\right)$ on the liability side of their balance sheets. Their equities are normalized to zero (Eq.39).

$$
L_{b}=D P^{b}+N W^{b}
$$

\subsubsection{Deposits}

Total bank deposits are equal to the sum of the household and firm deposits (Eq.40).

$$
D P^{b}=D P_{h}^{b}+D P_{f}^{b}
$$

The interest rate applied to deposits $\left(r^{d p}\right)$ is an exogenous parameter.

\subsubsection{Consumer Loans}

As is the case for firms, we simplify bank behavior to focus on the dynamics of household behavior. Particularly, we assume that banks provide all the loans demanded by households (Eq.41).

$$
L R_{h}=L D_{h}
$$

Principal payments due $\left(\widetilde{P P}^{h}\right)$ and interest payments due $\left(\widetilde{I P}^{h}\right)$ are calculated based on the outstanding loan stock $\left(\boldsymbol{L}_{\boldsymbol{b}}^{\boldsymbol{h}}\right)$ as in Eqs.42 and 43, respectively. The total loan payments due $\left(L P^{h}\right)$ is equal to the sum of these two amounts (Eq.44).

$$
\widetilde{P P}^{h}=\varphi \boldsymbol{L}_{\boldsymbol{b}}^{\boldsymbol{h}}
$$




$$
\begin{gathered}
\widetilde{I P}^{h}=r^{l n} \boldsymbol{L}_{\boldsymbol{b}}^{\boldsymbol{h}} \\
\widetilde{L P}^{h}=\widetilde{P P}^{h}+\widetilde{I P}^{h}
\end{gathered}
$$

Here $\varphi$ is the loan principal payment rate, and $r^{l n}$ is the loan interest rate. The loan interest rate is assumed to be determined by banks with a markup rate $(\mu)$ over the deposit interest rate (Eq.45).

$$
r^{l n}=(1+\mu) r^{d p}
$$

where $\mu>0$.

Banks collect loan payments $\left(L P^{h}\right)$ from households; however, the realized payments might be different from the payments due. In that case, we assume that the realized payments are first counted towards the interest part; then, the remaining part, if any, is counted towards principal payments (Eqs.46 and 47).

$$
\begin{gathered}
I P^{h}=\min \left[L P^{h}, \widetilde{I P}^{h}\right] \\
P P^{h}=L P^{h}-I P^{h}
\end{gathered}
$$

The change in the outstanding loan stock is equal to the difference between total realized loans and realized loan principal payments (Eq.48).

$$
\frac{d}{d t} \boldsymbol{L}_{\boldsymbol{b}}^{\boldsymbol{h}}=L R_{h}-P P^{h}
$$

\subsubsection{Profits}

Banks pay interest on household and firm deposits $\left(\boldsymbol{D} \boldsymbol{P}_{\boldsymbol{h}}^{\boldsymbol{b}}, \boldsymbol{D} \boldsymbol{P}_{\boldsymbol{f}}^{\boldsymbol{b}}\right)$ and receive interest payments from households for outstanding loans $\left(I P^{h}\right)$. Therefore, banks' profits are equal to the difference between their interest income and interest payments. As is the case for firms, banks are private companies owned by households and do not retain any part of their profits. Therefore, they distribute their profits to households with a constant delay (Eq.49).

$$
W P_{h}^{b}=I P_{-1}^{h}-r^{d p} \boldsymbol{D P}_{-\mathbf{1}}^{\boldsymbol{b}}
$$

\section{RESULTS}

The model is solved for the dynamic equilibrium conditions where all stocks are stable. The equilibrium values of household leverage $\left(L V_{h}^{*}\right)$ and consumption $\left(C^{h *}\right)$ are found as functions of exogenous parameters (Eqs. 50 and 51).

$$
\begin{gathered}
L V_{h}^{*}=\frac{\varphi}{\varphi-\rho \delta}-1 \\
C^{h *}=\left[1-\frac{r^{l n} \rho \delta \varpi}{\varphi}\right] \overline{Y D}_{h}^{*}
\end{gathered}
$$


Notably, as the share of consumer durables in the portfolio $(\rho)$ is an increasing function of CCI, the equilibrium level of household leverage increases with CCI. As for household consumption, the second term in the parentheses indicates the share of disposable income devoted to loan interest payments. Household consumption is equal to the household income left after interest payments. As the share of interest payments increases with the share of consumer durables in the portfolio, the share of household income devoted to consumption decreases with CCI.

We simulated the model for the baseline, the increase in consumer confidence, and the decrease in consumer confidence scenarios. The time unit of the simulations is chosen as months. Simulations are run for 1000 periods in order to observe the long-run dynamics. The initial value of perceived average disposable income is normalized to 1 in each scenario.

\subsection{The Baseline Scenario}

All the stocks are initiated at their equilibrium levels in the baseline scenario. CCI is equal to its normal value of 1 over the entire simulation period. The simulation results showed that all the variables stay at their equilibrium values over the simulation period (Figure 2). 
Figure 2. Dynamics of the Key Variables in the Economy in the Baseline Scenario
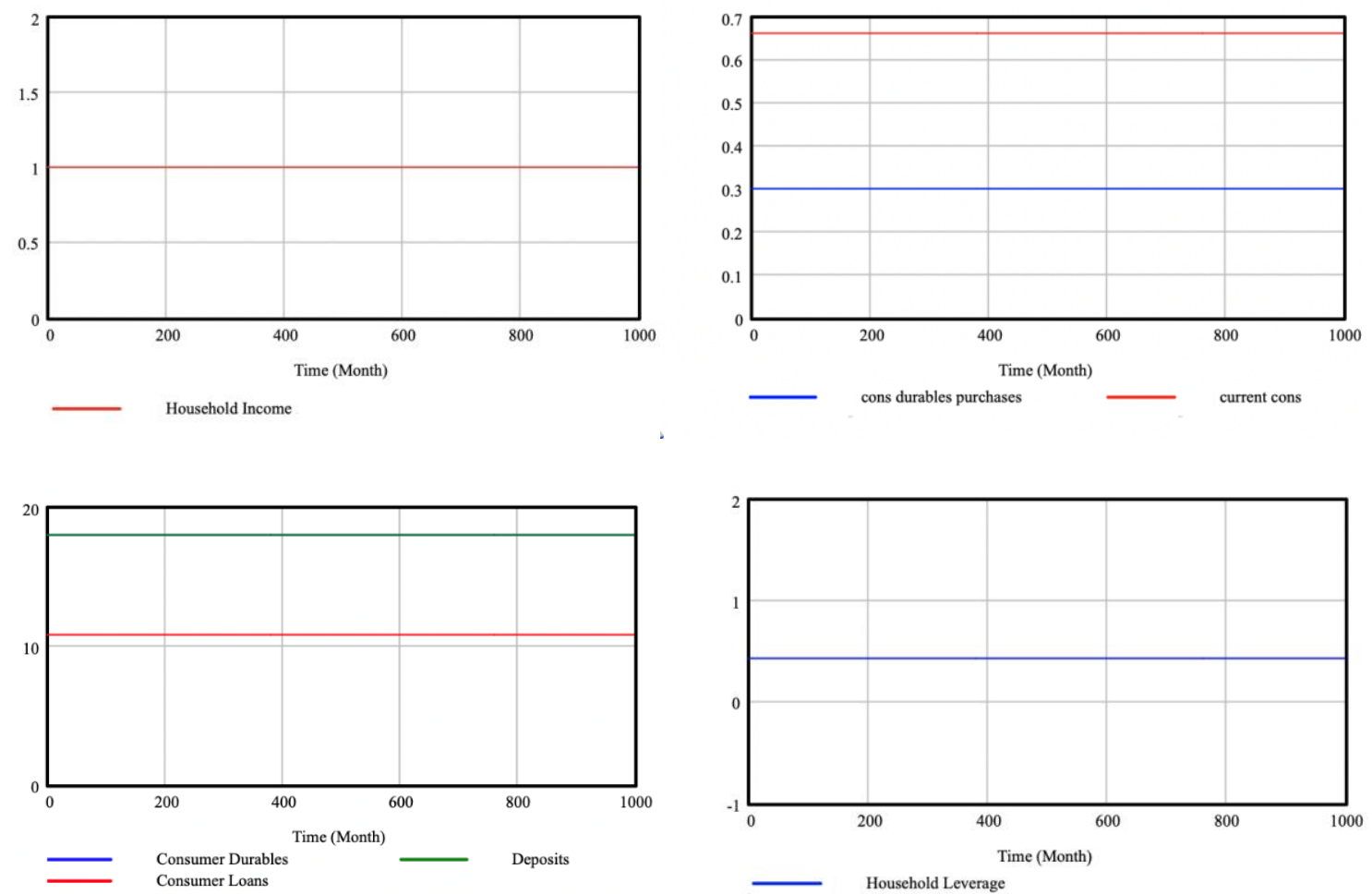

\subsection{The Increase in Consumer Confidence Scenario}

In the increase in consumer confidence scenario, all the stocks are initiated at their equilibrium values. Then at period 50, the CCI increases from 1 to 1.25 due to an exogenous shock. The dynamic behavior of the key variables in the economy is presented in Figure 3.

The immediate effect of the increase in CCI changes the desired composition of the household portfolio. Being more confident about the future, households want to increase the share of consumer durables and decrease the share of bank deposits in their portfolio. As the target level of consumer durables increases above the actual level, consumer durables purchases turn positive. On the other hand, as the target level of bank deposits decreases below the actual level, desired savings turn negative, which causes an increase in discretionary consumption. As a result of these two effects, household income starts to increase.

Following the increase in household disposable income, the standard of living starts to increase, which kicks off the positive feedback loops that sustain household income growth. Firstly, the increase in the standard of living causes a further increase in the consumer durables goods target, increasing 
consumer durables purchases (R1). ${ }^{3}$ Secondly, the increase in the standard of living increases discretionary household consumption (R4). Finally, as household disposable income increases faster than household spending at the beginning, bank deposits start to increase, which supports the increase in discretionary consumption through the wealth effect (R5).

Besides these reinforcing feedback loops, there are also balancing feedback loops working towards stabilizing the economy. Notably, the deposit target increases with the standard of living, which puts upward pressure on desired savings (B1). Moreover, consumer loans stock, and hence, loan payments due, increases with consumer durables purchases (B7). Both of these effects slow down the increase in discretionary household consumption. The increase in household disposable income and consumer durables target slows down accordingly. Moreover, with the consumer durables purchases being above depreciation, the actual level of consumer durables stock continues to increase. As a result of the reduction in the gap between the target and actual levels, consumer durables purchases slow down (B4).

These balancing loops gain strength with the increases in standard of living, consumer loan and consumer durables stocks. However, they cannot stabilize the economy in a timely manner due to the significant delays they involve. The increase in CCI exacerbates the problem by increasing the delays in the negative feedback loops while reducing the delays in the positive loops. Specifically, a higher CCI decreases both the consumer durables adjustment time and the desired discretionary consumption adjustment time, and it also increases the bank deposit adjustment time. Therefore, the relative strength of the reinforcing feedback loops that drive the income growth increases compared to that of the balancing loops. Moreover, the increase in CCI inhibits the credit constraint loop by increasing the desired share of loan payments in expected income. Thus, the consumer loan stock can reach higher levels without hitting the credit constraint. As a result, household income, consumption, and leverage overshoot and exhibit damping oscillations around their new equilibrium levels, which are higher than in the baseline scenario.

As Eq.50 suggests, the equilibrium level of household leverage increases with CCI. This is because the share of consumer durables in the portfolio increases, which means a corresponding increase in the consumer loan stock. This means that the size of consumer loans relative to household wealth increases, which then causes a decrease in the relative size of household net worth. Therefore, household leverage increases both because of the increase of debt stock relative to the size of household net worth. Additionally, household consumption increases with the increase in household disposable income.

\footnotetext{
${ }^{3}$ The feedback loops that play a role in the mentioned process are given in parentheses and are indicated in Figure 1, representing the dynamic hypothesis.
} 
However, as Eq.51 suggests, the share of disposable income devoted to consumption decreases due to the increased share of interest payments.

Figure 3. Dynamics of the Key Variables in the Economy in the Increase in CCI Scenario
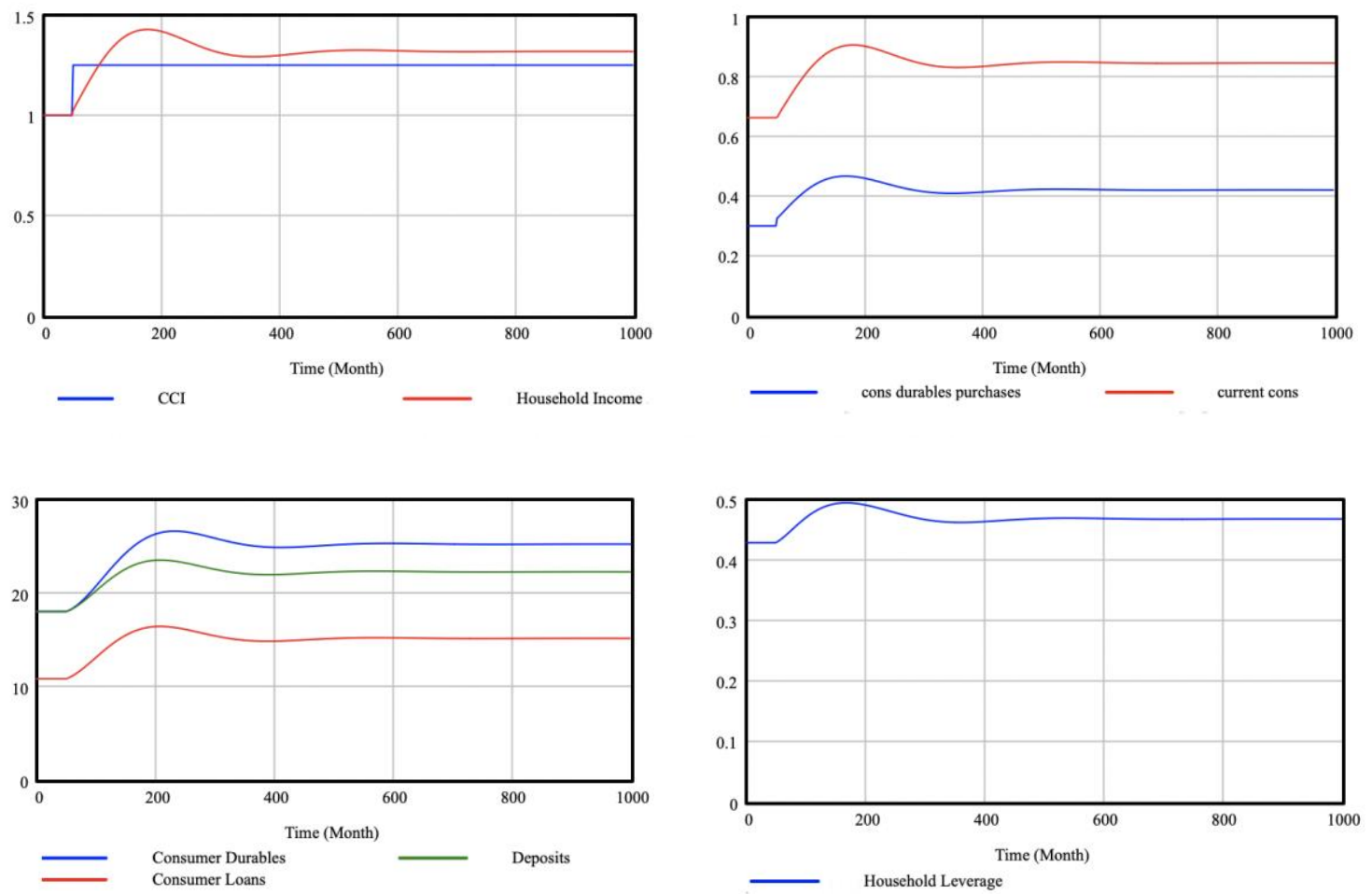

We also conducted a sensitivity analysis for the parameters that measure the sensitivity of household behavior to CCI. The results are shown in Figure 4. Firstly, $\gamma_{1}$ is the parameter that measures the sensitivity of household portfolio choice to changes in CCI. Both the equilibrium level of household income and the amplitude of oscillations in the transition process increase with an increase in this parameter. $\gamma_{2}$ and $\gamma_{3}$ are the parameters that govern the sensitivity of portfolio adjustment behavior to changes in CCI. As expected, the economy destabilizes as households become more responsive. Specifically, while the equilibrium level of household income does not change, the amplitude of fluctuations around this level increases with an increase in any of these parameters. $\gamma_{4}$ measures the sensitivity of desired discretionary consumption to changes in CCI. This parameter does not affect the stability properties of the economy as much as the previous two. The initial overshooting slightly increases with an increase in $\gamma_{4}$. Finally, a change in $\gamma_{5}$ or $\gamma_{6}$ does not affect the behavior of the economy, as the credit constraint and the spending constraint are not binding in this scenario.

\subsection{The Decrease in Consumer Confidence Scenario}


In the decrease in consumer confidence scenario, all the stocks are initiated at their equilibrium values. Then at period 50, CCI decreases from 1 to 0.75 due to an exogenous shock. The dynamic behavior of the key variables in the economy is presented in Figure 5.

When CCI falls, households' desired share of consumer durables in the portfolio decreases, and desired share of bank deposits increases. With the target level of consumer durables being below the actual level, households' consumer durables purchases decreases. On the other hand, as the target level of bank deposits is above its actual level, desired savings turn positive, which causes a decrease in discretionary consumption. As a result of these two effects, household income and the standard of living start to decrease.

In this case, reinforcing feedback loops start working towards decreasing household income. The consumer durables target decreases with the standard of living, which causes a decrease in consumer durables purchases (R1). The decrease in the standard of living also decreases discretionary consumption (R4). As household disposable income decreases faster than spending initially, bank deposits decrease, which supports the decrease in discretionary consumption with the wealth effect (R5).

While they were not in action in the increase in consumer confidence scenario, credit and spending constraints play important roles in the decrease in household income in this scenario. The first is credit constraint. The decrease in CCI makes households willing to devote a lower share of their future income to loan payments. When the desired share of loan payments decreases below the actual share, credit constraint kicks in and lowers the loan demand further. However, as household disposable income decreases (R3) and desired savings increases with the decrease in bank deposits (R2), the actual share of loan payments in income increases, and the credit constraint decreases the consumer durables purchases even further. The second is spending constraint. With the decrease in CCI, households want to hold more deposits as a buffer against future contingencies. When the actual deposit buffer ratio falls below the desired ratio, the spending constraint kicks in, and discretionary consumption falls further. Moreover, the decrease in bank deposits resulting from the decrease in disposable income causes the actual deposit buffer ratio to fall (R6), and the spending constraint decreases discretionary consumption even further. 


\section{Figure 4. Sensitivity Analysis for the Increase in CCI Scenario}
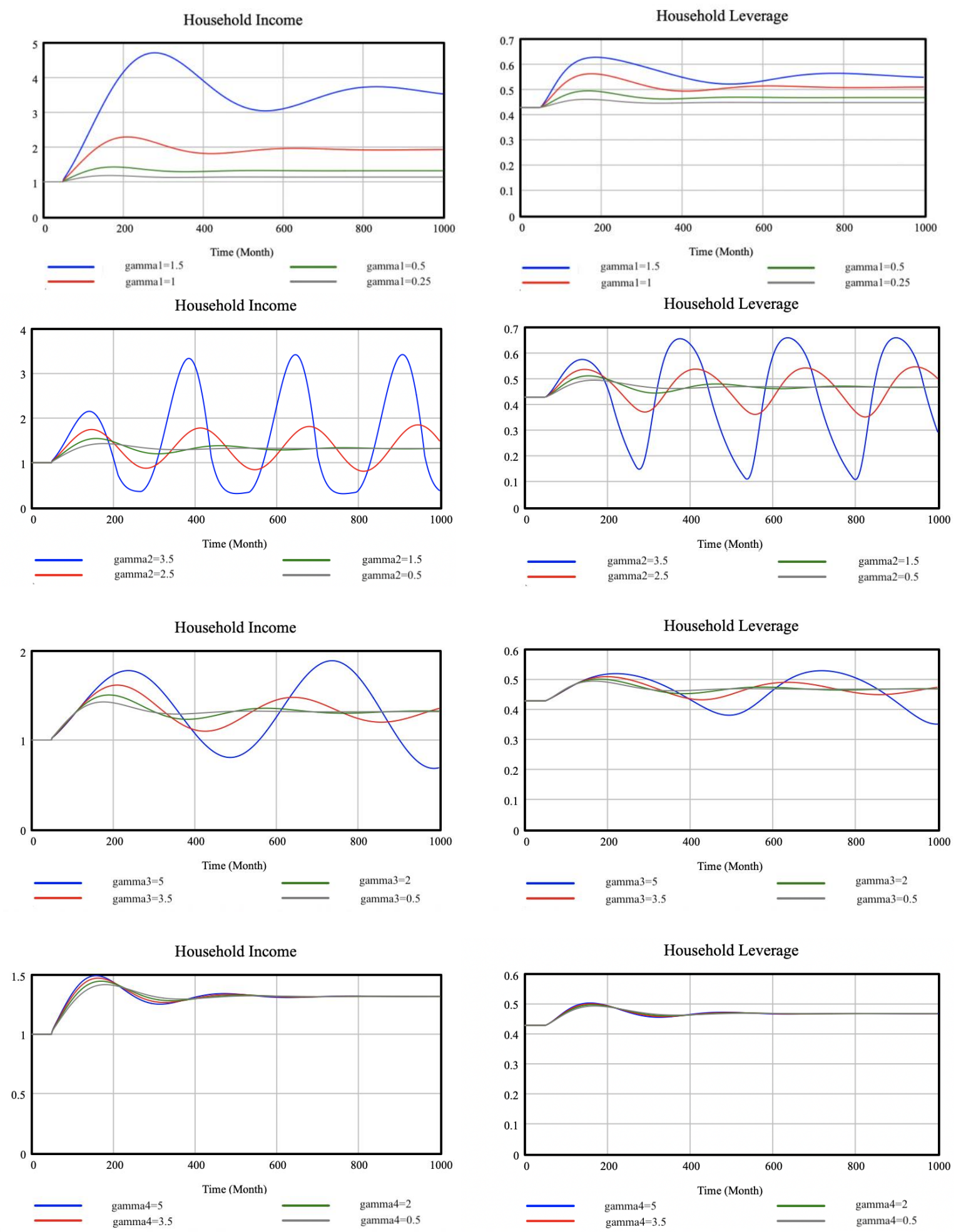
Besides these reinforcing feedback loops, the balancing feedback loops are working towards preventing household income from decreasing further. Notably, the deposit target decreases with the decrease in the standard of living, decreasing desired saving (B1). Additionally, consumer loans and loan payments due decreases due to decreased loan demand (B5) and due to loan payments (B6). These two effects slow down the decrease in discretionary consumption. With the decreases in discretionary consumption and the loan payments due, desired total spending decreases, which works toward increasing the actual deposit buffer ratio and relaxing the spending constraint (B8). The decreases in loan payments due (B5) and desired saving (B2) also work towards decreasing the actual share of loan payments in expected income left, hence, relaxing the credit constraint. Moreover, with the consumer durables purchase being below depreciation, the actual level of consumer durables stock continues to decrease. As a result of the increasing gap between the target and actual levels, the desired consumer durables adjustment increases (B4), which constitutes the basis for an increased demand in consumer durables when credit constraint loosens.

These balancing loops gain strength with the decreases in the standard of living, consumer loan and consumer durables stocks. As was the case in the increasing consumer confidence scenario, they fail to stabilize the economy in a timely manner due to significant delays they involve. The decrease in the CCI exacerbates the problem by increasing the delays in the negative feedback loops while reducing the delays in the positive feedback loops. Specifically, a lower CCI increases both the consumer durables adjustment time and the desired discretionary consumption adjustment time and decreases the bank deposit adjustment time. Moreover, the decrease in CCI increases the strengths of the loops involving the credit constraint by decreasing the desired share of loan payments in expected income and the loops involving the spending constraint by increasing the desired deposit buffer ratio. As a result, household income, consumption, and leverage overshoot and exhibit damping oscillations around their new equilibrium levels, which are lower than in the baseline scenario.

As suggested by Eq.50, the equilibrium level of household leverage decreases with the decrease in CCI because of the lower relative size of debt stock that households are comfortable with holding at dynamic equilibrium. Even though the level of household consumption decreases with the decrease in household income, the share of disposable income devoted to consumption increases due to the decreased share of interest payments (Eq.51).

We conducted a sensitivity analysis in this scenario as well. The results are shown in Figure 6. The new equilibrium levels of household income and leverage decrease as $\gamma_{1}$ increases. While the equilibrium level of household income and leverage slightly decreases with $\gamma_{2}$, the amplitude of initial overshooting does not change. On the other hand, a change in $\gamma_{3}$ or $\gamma_{4}$ does not affect the equilibrium level of household income and leverage. However, the amplitude of initial overshooting decreases with an increase in these parameters. Finally, since the credit constraint and the spending constraint are the main mechanisms that govern the decrease in income, a change in parameters governing the sensitivity 
of these behaviors to CCI affects the dynamics of the system. Specifically, an increase in $\gamma_{5}$ or $\gamma_{6}$ results in a decrease in the equilibrium level of household income. On the other hand, while an increase in $\gamma_{5}$ decreases household leverage, the effect of an increase in $\gamma_{6}$ on leverage is ambiguous.

Figure 5. Dynamics of the Key Variables in the Economy in the Decrease in CCI Scenario

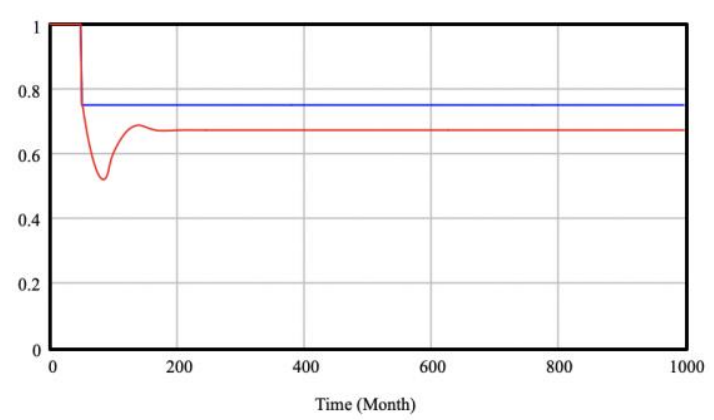

$-\quad \mathrm{CCI}$

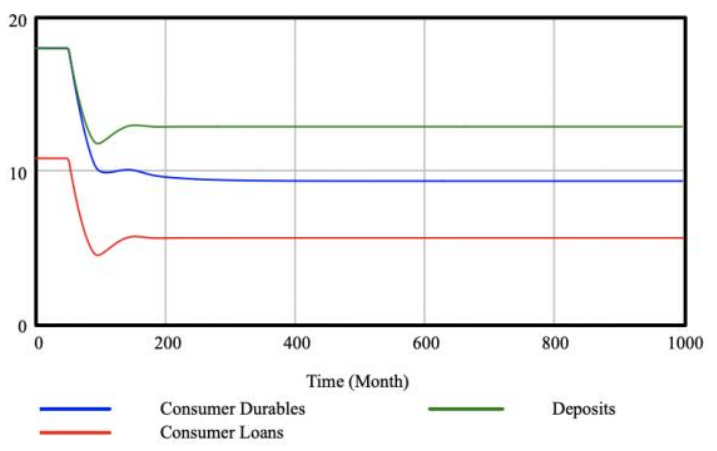

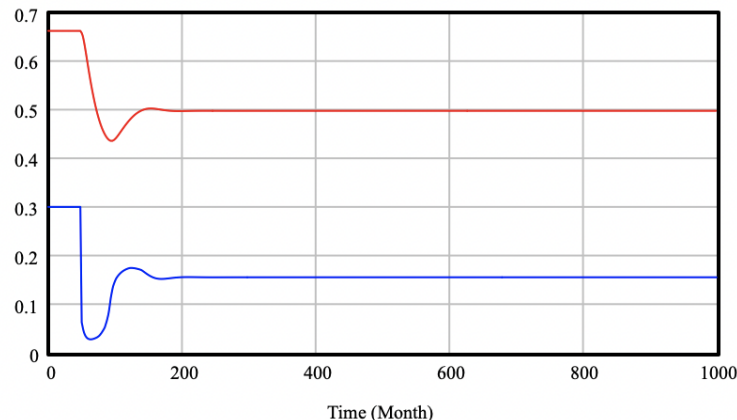

cons durables purchases

current cons

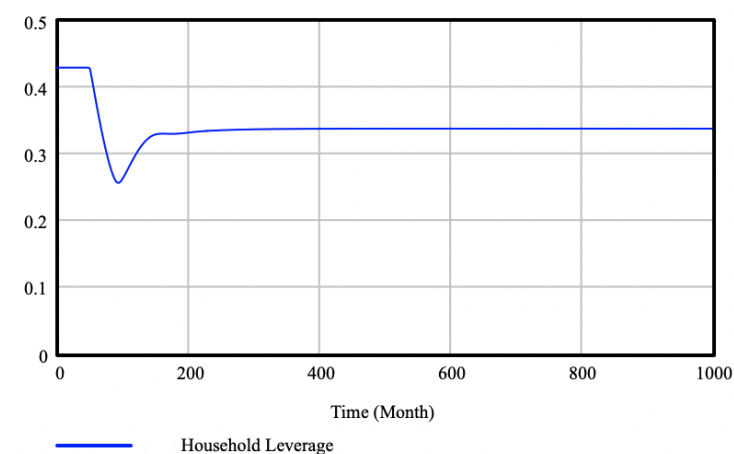

Figure 6. Sensitivity Analysis for the Decrease in CCI Scenario
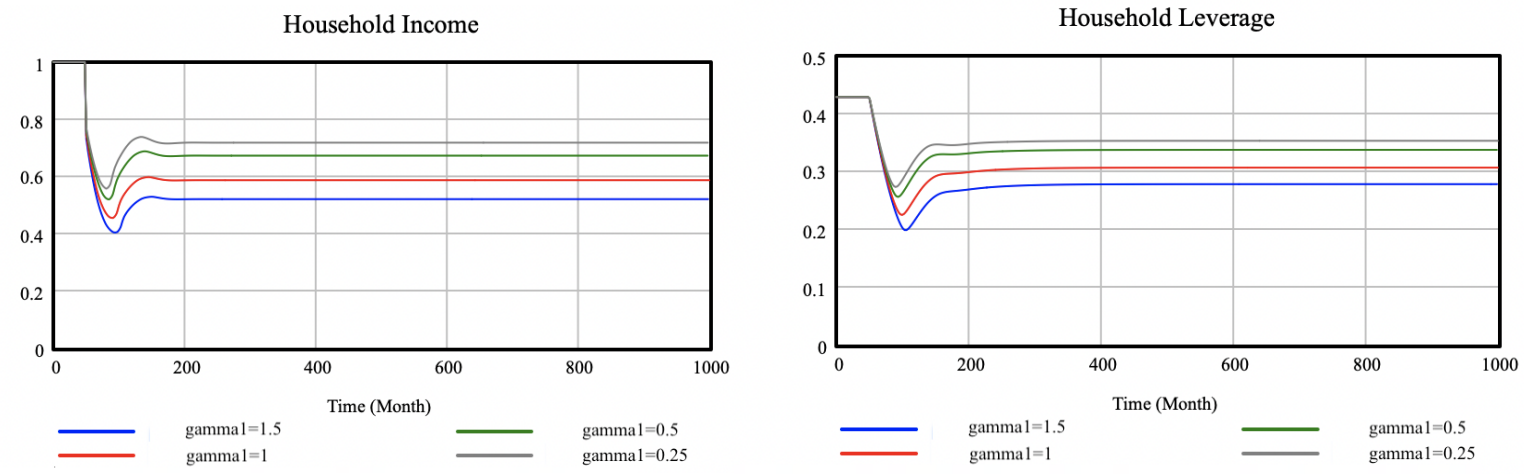
Yönetim ve Ekonomi Araștırmaları Dergisi / Journal of Management and Economics Research Cilt/Volume: 19 Sayl/Issue: 2 Haziran/June 2021 ss. /pp. 62-87

S. Şahin Doi: http://dx.doi.org/10.11611/yead.877321

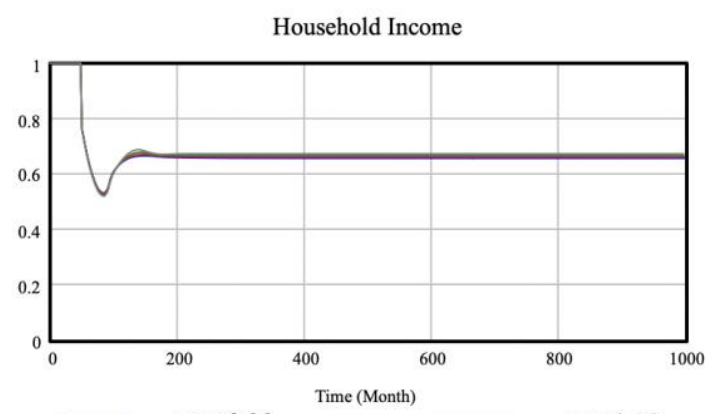

$\longrightarrow \begin{array}{r}\text { gamma2 }=3.5 \\ \text { gamma2 } 2.5\end{array} \quad-\quad \begin{array}{r}\text { gamma2 }=1.5 \\ \text { gamma2 }=0.5\end{array}$

Household Income

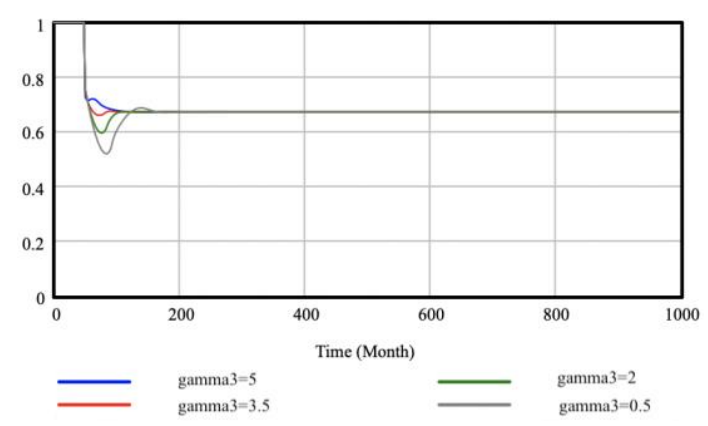

Household Income

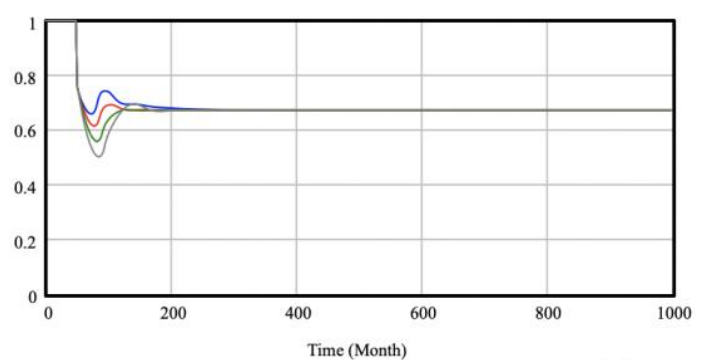

$\longrightarrow \begin{aligned} & \text { gamma4=5 } \\ & \text { gamma4=3.5 }\end{aligned} \quad \longrightarrow \quad \begin{aligned} & \text { gamma4=2 } \\ & \text { gamma4 }=0.5\end{aligned}$
Household Leverage

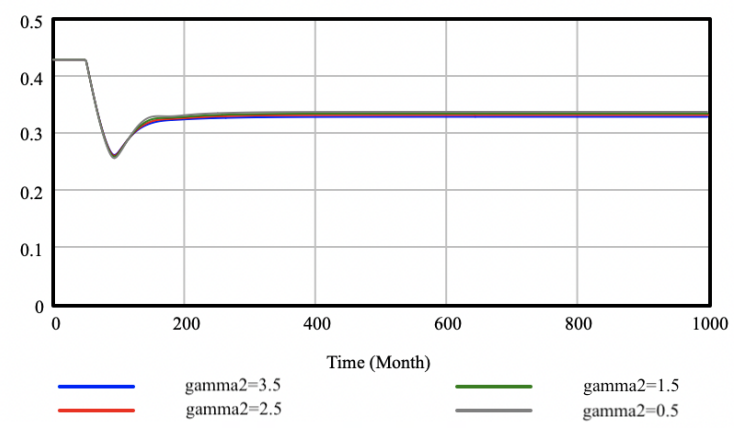

Household Leverage

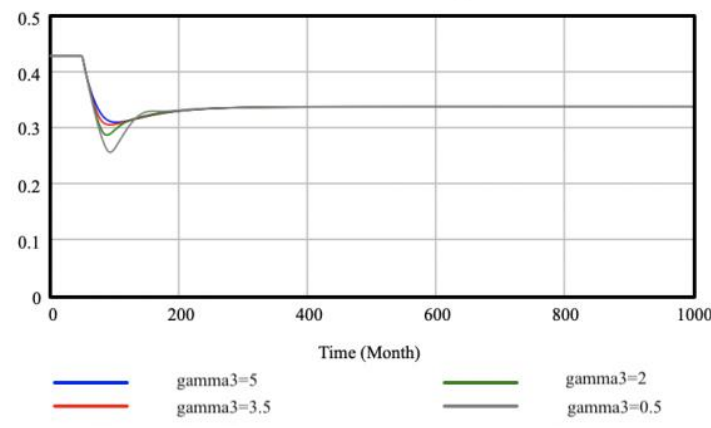

Household Leverage

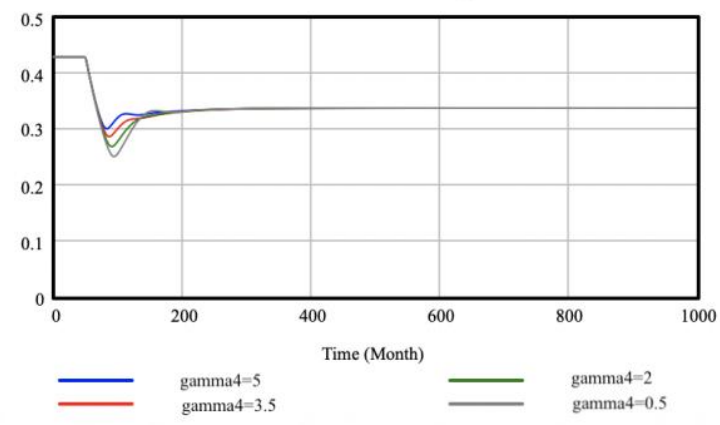

Figure 6. Sensitivity Analysis for the Decrease in CCI Scenario (Continued)
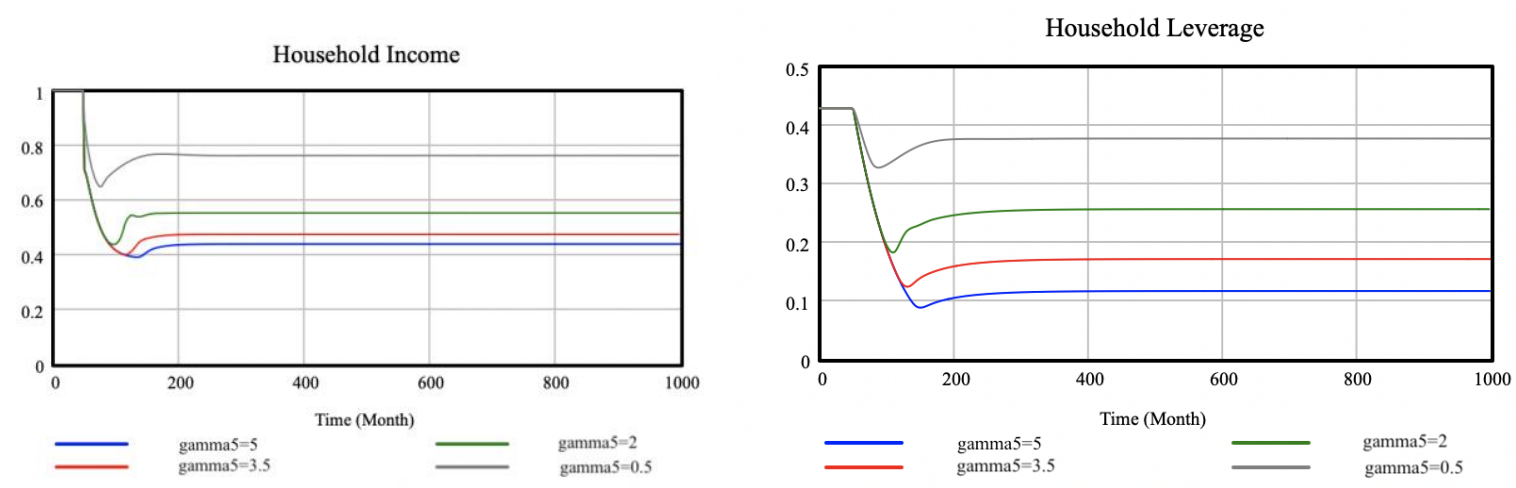

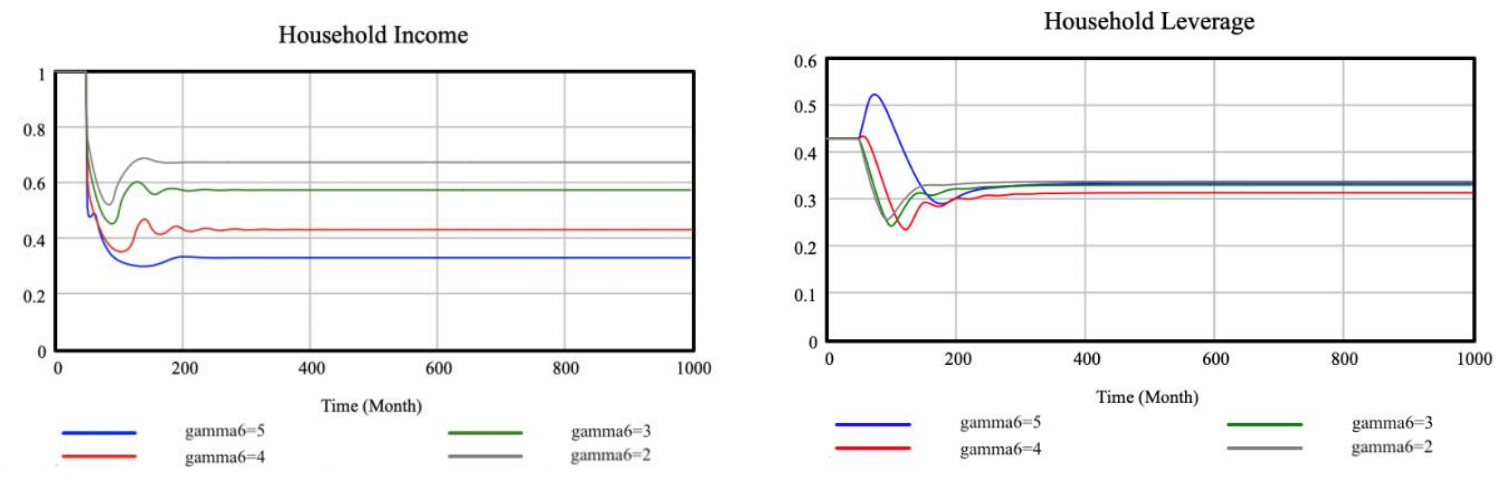

\section{CONCLUSION}

In this study, we developed a stock-flow-consistent system dynamics model to explain the effects of consumer confidence on aggregate household income, consumption, and leverage. Specifically, we allowed consumer confidence to affect household portfolio choice, consumption, and borrowing behaviors.

The simulations of our model showed that consumer confidence has profound effects on the macroeconomic dynamics of the economy. Specifically, household income, consumption, and leverage move in the same direction with consumer confidence. All these variables overshoot during the transition to the new equilibrium levels due to the existence of significant delays in the negative feedback loops. Moreover, the change in the CCI exacerbates the problem by strengthening the positive feedback loops and weakening the negative feedback loops.

The results of the sensitivity analysis showed that the stability properties of the economy are determined by psychological parameters of households that govern the sensitivity of household behavior to CCI. The sensitivity of households' consumer durables and bank deposit adjustment times to CCI in particular, determine whether the variables exhibit converging, continuous, or diverging oscillations around equilibrium values.

\section{REFERENCES}

Bertola, G., Guiso, L. and Pistaferri, L. (2005) “Uncertainty and Consumer Durables Adjustment”, The Review of Economic Studies, 72(4), 973-1007.

Blanchard, O. (1993) "Consumption and the Recession of 1990-1991", The American Economic Review, 83(2), 270-274.

Bryant, W. A., \& Macri, J. (2005) “'Does Sentiment Explain Consumption?”, Journal of economics and finance, 29(1), 97-110.

Carroll, C. D. (1992) "The Buffer-Stock Theory of Saving: Some Macroeconomic Evidence', Brookings Papers on Economic Activity, 1992(2), 61-156. 
Carroll, C. D. (2004) “Theoretical Foundations of Buffer Stock Saving (Tech. Rep.)”, National Bureau of Economic Research.

Carroll, C. D., Fuhrer, J. C., \& Wilcox, D. W. (1994) “Does Consumer Sentiment Forecast Household Spending? If So, Why?’' The American Economic Review, 84(5), 1397-1408.

Carroll, C. D., \& Samwick, A. A. (1995) “The Nature of Precautionary Wealth (Tech. Rep.)”, National Bureau of Economic Research.

Côté, D., \& Johnson, M. (1998) “Consumer Attitudes, Uncertainty, and Consumer Spending”, No. 1998-16, Bank of Canada.

Deaton, A. (1991) “'Saving and Liquidity Constraints”, Econometrica, 59(5), 221-248.

Dees, S., \& Brinca, P. S. (2013) “Consumer Confidence as a Predictor of Consumption Spending: Evidence for the United States and the Euro Area", International Economics, 134, 1-14.

Dow, A., \& Dow, S. C. (2011) “Animal Spirits Revisited”, Capitalism and Society, 6(2).

Franke, R. (2012) “Microfounded Animal Spirits in the New Macroeconomic Consensus”, Studies in Nonlinear Dynamics \& Econometrics, 16(4).

Garner, C. A. (1981) 'Economic Determinants of Consumer Sentiment', Journal of Business Research, 9(2), 205-220.

Geiger, N. (2016) "Psychological Elements in Business Cycle Theories: Old Approaches and New Insights", The European Journal of the History of Economic Thought, 23(3), 478-507.

Godley, W., \& Lavoie, M. (2006) “Monetary Economics: an Integrated Approach to Credit, Money, Income, Production and Wealth. Springer.

Grieves, R. (1983) “The Demand for Consumer Durables”, Journal of Money, Credit and Banking, 15(3), 316-326.

Hymans, S. H. (1970) “Consumer Durable Spending: Explanation and Prediction”, Brookings Papers on Economic Activity, 1(2), 173-206.

Juster, F., \& Wachtel, P. (1972) “Anticipatory and Objective Models of Durable Goods Demand”, American Economic Review, 62(4), 564-79.

Katona, G. (1947) “Contribution of Psychological Data to Economic Analysis”, Journal Of The American Statistical Association, 42(239), 449-459.

Katona, G. (1949) "Effect of Income Changes on the Rate of Saving”, The Review of Economics and Statistics, 95-103.

Katona, G. (1951). Psychological Analysis of Economic Behavior’, McGraw-Hill. 
Katona, G. (1957) “Federal Reserve Board Committee Reports on Consumer Expectations and Savings Statistics", The Review of Economics and Statistics, 40-45.

Katona, G. (1968) 'CConsumer behavior: Theory and Findings on Expectations and Aspirations', The American Economic Review, 58(2), 19-30.

Katona, G. (1971) “'Consumer Durable Spending”, Brookings Papers on Economic Activity, 1971(1), 234-239.

Katona, G. (1974) '“Psychology and Consumer Economics”, Journal of Consumer Research, 1-8.

Katona, G. (1975) “'Psychological Economics”, Elsevier.

Katona, G. (1980) “'How Expectations are Really Formed”, Challenge, 23(5), 32-35.

Keynes, J. M (1921) “A Treatise on probability”, London: Macmillan.

Keynes, J. M. (1936) “The General Theory of Employment, Interest, and Money”, Macmillan \& Co., Ltd.

Kindleberger, C. P., \& Aliber, R. Z. (2005) “Manias, Panics and Crashes: A History of Financial Crises", fifth edition, Palgrave Macmillan.

Loewenstein, G., \& O'Donoghue, T. (2004) “Animal Spirits: Affective and Deliberative Processes in Economic Behavior', Available at SSRN 539843.

Marchionatti, R. (1999) “'On Keynes’ Animal Spirits”, Kyklos, 52(3), 415-439.

Minsky, H. P. (1977) “The Financial Instability Hypothesis: an Interpretation of Keynes and an Alternative to 'Standard' Theory', Challenge, 20(1), 20-27.

Mishkin, F. S. (1976) “Illiquidity, Consumer Durable Expenditure, and Monetary Policy', The American Economic Review, 642-654.

Mishkin, F. S. (1978) “Consumer Sentiment and Spending on Durable Goods”, Brookings Papers on Economic Activity, 1978(1), 217-232.

Pickering, J. (1993) “The Durable Purchasing Behaviour of The Individual Household”, European Journal Of Marketing, 12(2), 178-193.

Sandmo, A. (1970) “The Effect of Uncertainty on Saving Decisions", The Review of Economic Studies, 37(3), 353-360.

Smith, A. (2002) "The Theory of Moral Sentiments", Edited By Knud Haakonssen. Cambridge: Cambridge University Press.

Sterman, J. D. (2000) “'Business Dynamics: System Thinking and Modeling for a Complex World”, Irwin/Mcgraw-Hill. 
Throop, A. W. (1992) “Consumer Sentiment: Its Causes and Effects”, Federal Reserve Bank Of San Francisco Economic Review, 1, 35-59.

Tobin, J. (1958) 'Liquidity Preference as Behavior Towards Risk', The Review of Economic Studies, $25(2), 65-86$.

Vuchelen, J. (2004) "Consumer Sentiment and Macroeconomic Forecasts", Journal of Economic Psychology, 25(4), 493-506.

Wadud, M., Ahmed, H. J. A., \& Tang, X. (2020) “Factors Affecting Delinquency of Household Credit In The US: Does Consumer Sentiment Play A Role?', The North American Journal Of Economics And Finance, 52, 101132.

Hakem Değerlendirmesi: Dış bağımsız.

Çıkar Çatışması: Yazar çıkar çatışması bildirmemiştir.

Finansal Destek: Yazar bu çalışma için finansal destek almadığını beyan etmiştir.

\section{Teşekkür:}

Peer-review: Externally peer-reviewed.

Conflict of Interest: The author has no conflict of interest to declare.

Grant Support: The author declared that this study has received no financial support.

Acknowledgement: 